\title{
Avrupa Birliği Adalet Divanı Kararları Işığında Terörizm ile İlişkisi Olan Kişilerin Mülteci Statüsünden Hariç Bırakılması
}

\author{
Meltem İneli Ciğere ${ }^{*}$
}

Öz

Terörizm günümüzde uluslararası barış ve güvenlik kadar ulusal güvenlik ve kamu düzenini de tehdit etmektedir. Terör saldırılarının son yıllarda artı̧ göstermesi ile devletler terör ile ilişkisi olan yabancıları mülteci statüsünden hariç tutma yoluna daha sık başvurmaya başlamıştır. Terör ile ilişkisi olan yabancıların mülteci statüsünden hariç bırakılması 1951 tarihli Mültecilerin Hukuki Durumuna İlişkin Cenevre Sözleşmesi'nin (1951 Sözleşmesi) 1. maddesinin F fikrası kapsamında incelenmektedir. 1951 Sözleşmesi m. 1 F’yi esas alan düzenlemeler hem Avrupa Birliği Hukukunda hem de hukukumuzda yer almaktadır. Avrupa Birliği Adalet Divanı verdiği kararlar ile bugüne kadar terörizm ve mülteci statüsünden hariç bırakmaya ilişkin önemli birçok hususu açığa kavuşturmuştur. Bu çalışmada Avrupa Birliği Adalet Divanı'nın 9 Kasım 2010 tarih ve C-57/09 ve C-101/09 sayılı B ve D Kararı, 24 Haziran 2015 tarih ve C 373/13 sayılı T Kararı ve 31 Ocak 2017 tarih ve C-573/15 sayılı Lounani Kararı incelenmek suretiyle terör ile ilişkisi olan kişilerin mülteci statüsünden hariç bırakılması konusu ele alınacaktır. Makalede Avrupa Birliği Adalet Divanı’nın terör ile ilişkisi olan kişilerin mülteci statüsünün dışında bırakılmasına ilişkin ortaya koyduğu ilkeler tespit edilecek ve Divan'ın 1951 Sözleşmesi m. 1 F'yi esas alan 2011/95/EU sayılı AB Vasıf Yönergesi m. 12'de yer alan düzenlemeleri ne şekilde yorumladığı ortaya konulacaktır.

\author{
Anahtar Kelimeler \\ Terörizm • ABAD • Mülteci • Hariç bırakma • Lounani Kararı • AB Vasıf Yönergesi m. 12 • 1951 Sözleşmesi m. $1 \mathrm{~F} \bullet$ Ulusal \\ güvenlik \\ Exclusion of Persons Who Have Links with Terrorism From Refugee Status In View of the Court of Justice \\ of the European Union's Judgments
}

\begin{abstract}
Today, terrorism threatens not just international peace and security but also national security and public order. With the increase of terrorist attacks in recent years, states have been implementing stricter policies and excluding more foreigners who have links with terrorism from refugee status. Exclusion of persons who have links with terrorism from refugee status falls within the scope of Article $1 \mathrm{~F}$ of the Convention relating to the Status of Refugees (1951 Convention). Similar provisions to Article $1 \mathrm{~F}$ of the 1951 Convention can be found in European Union Law and Turkish Law. The Court of Justice of the European Union (CJEU) has clarified a number of important issues related to terrorism and exclusion over the years. In this study, the principles introduced by the CJEU on the exclusion of persons who have links with terrorism from refugee status will be identified through an analysis of the following decisions: Bundesrepublik Deutschland v B (C-57/09) and D (C-101/09), H. T. v Land Baden-Württemberg, C 373/13 and Commissaire général aux réfugiés et aux apatrides v. Mostafa Lounani, C-573/15. In doing so, how the CJEU interprets Article 12 of the Directive 2011/95/EU of the European Parliament and of the Council which is modelled after Article $1 \mathrm{~F}$ of the 1951 Convention will be outlined.
\end{abstract}

\section{Keywords}

Terrorism • CJEU • Refugee • Exclusion • Lounani Case • EU Qualification Directive art. $12 \bullet 1951$ Convention art. 1 F • National security

\footnotetext{
* Sorumlu Yazar: Meltem İneli Ciğer (Dr Öğr. Üyesi), Süleyman Demirel Üniversitesi, Hukuk Fakültesi, Milletlerarası Hukuk Anabilim Dalı, Isparta, Türkiye. Eposta: meltemciger@sdu.edu.tr

Attf: İneli Ciğer, Meltem, “Avrupa Birliği Adalet Divanı Kararları Işığında Terörizm ile iliş̧kisi Olan Kişilerin Mülteci Statüsünden Hariç Bırakılması", İstanbul Hukuk Mecmuası, 76/2, 2018, 667-690. https://doi.org/10.26650/mecmua.2018.76.2.0021
} 


\section{Extended Summary}

Today, terrorism threatens not just international peace and security but also national security and public order. With the increase of terrorist attacks in recent years, states have been implementing stricter policies and excluding more foreigners who have links with terrorism from refugee status. Exclusion from refugee status is regulated under Article $1 \mathrm{~F}$ of the Convention relating to the Status of Refugees (1951 Convention) as follows:

"The provisions of this Convention shall not apply to any person with respect to whom there are serious reasons for considering that:

(a) he has committed a crime against peace, a war crime, or a crime against humanity, as defined in the international instruments drawn up to make provision in respect of such crimes;

(b) he has committed a serious non-political crime outside the country of refuge prior to his admission to that country as a refugee;

(c) he has been guilty of acts contrary to the purposes and principles of the United Nations."

Similar provisions to Article $1 \mathrm{~F}$ of the 1951 Convention can be found in European Union Law and Turkish Law. Council Directive 2004/83/EC of 29 April 2004 on minimum standards for the qualification and status of third country nationals or stateless persons as refugees or as persons who otherwise need international protection and the content of the protection granted (Qualification Directive) clarified who is eligible for refugee status and subsidiary protection in the EU and who would be excluded from these statuses. Directive 2011/95/EU of the European Parliament and of the Council of 13 December 2011 on standards for the qualification of thirdcountry nationals or stateless persons as beneficiaries of international protection, for a uniform status for refugees or for persons eligible for subsidiary protection, and for the content of the protection granted (Recast Qualification Directive) has replaced the Qualification Directive for all EU Member States except the United Kingdom and Ireland in 2013.

Exclusion from refugee status has been regulated under Article 12 of the Qualification Directive and Article 12 of the Recast Qualification Directive in a very similar manner. Article 12 paras (2) and (3) of the Recast Qualification Directive establishes rules for exclusion from refugee status, which are modelled after Article $1 \mathrm{~F}$ of the 1951 Convention, as follows:

"2. A third-country national or a stateless person is excluded from being a refugee where there are serious reasons for considering that:

(a) he or she has committed a crime against peace, a war crime, or a crime against humanity, as defined in the international instruments drawn up to make provision in respect of such crimes;

(b) he or she has committed a serious non-political crime outside the country of refuge prior to his or her admission as a refugee, which means the time of issuing a residence permit based on the granting of refugee status; particularly cruel actions, even if committed with an 
allegedly political objective, may be classified as serious non-political crimes;

(c) he or she has been guilty of acts contrary to the purposes and principles of the United Nations as set out in the Preamble and Articles 1 and 2 of the Charter of the United Nations.

3. Paragraph 2 applies to persons who incite or otherwise participate in the commission of the crimes or acts mentioned therein."

Terrorism, membership of a terrorist group or committing terrorist acts are not identified clearly as exclusion grounds under Article $1 \mathrm{~F}$ of the 1951 Convention though exclusion of persons who have links with terrorism mostly falls within the scope of Article $1 \mathrm{~F}$ paras (b) and (c) as well as Article 12 paras (2) and (3) of the Recast Qualification Directive. The Court of Justice of the European Union (CJEU) has over the years clarified a number of important issues related to Article 12 of the Recast Qualification Directive as well as terrorism and exclusion.

In this study, the principles introduced by the CJEU on exclusion of persons who have links with terrorism from refugee status will be identified through an analysis of the following decisions: Bundesrepublik Deutschland v B (C-57/09) and D (C101/09), H. T. v Land Baden-Württemberg, C 373/13 and Commissaire général aux réfugiés et aux apatrides v. Mostafa Lounani, C-573/15. In doing so, how the CJEU interprets Article 12 of the Recast Qualification Directive which is modelled after Article $1 \mathrm{~F}$ of the 1951 Convention will be outlined. 


\section{Giriş}

Terörizm günümüzde uluslararası barış ve güvenliğe karşı en ciddi tehditlerden birini oluşturmaktadır. ${ }^{1}$ New York 9/11 saldırıları, Londra'da 7 Temmuz 2005'te gerçekleşen bombalı saldırılar, 2015 Paris saldırıları, 2017 Manchester Arena saldırısı gibi terör eylemleri devletlerin ulusal güvenlik konusundaki endişelerinin artmasına ve terörle mücadele ile ilgili daha katı önlemler almalarına sebep olmuştur. ${ }^{2}$ Her ne kadar bu eylemleri gerçekleştiren kişilerin çoğunluğu mülteci olmasa da bu gelişmeler ile birçok devlet mülteci statüsünden hariç bırakma/hariç tutma (exclusion) hükümlerinin uygulama alanını genişletmeye yönelik girişimlerde bulunmuştur. ${ }^{3}$ Zamanla birçok devlet terör ile ilişkisi olan yabancıları mülteci statüsünden hariçte bırakma yoluna daha sık başvurmaya başlamıştır. ${ }^{4}$

Uluslararası hukukta terörizm, terör örgütü, terör faaliyetleri ve terör suçu kavramlarını kesin ve açık olarak tanımlayan tek bir belge bulunmamakla birlikte bu kavramlar günümüzde mülteci statüsünden hariç bırakma için büyük önem arz etmektedir. ${ }^{5}$ Bugün, terörizm ile ilişkisi olan kişilerin ${ }^{6}$ uluslararası koruma kapsamı dışında bırakılması konusu terör eylemlerinin hedefinde olan Türkiye gibi birçok ülke için hayati bir önem taşımaktadır.

Mülteci statüsünden hariç bırakma 1951 tarihli Mültecilerin Hukuki Durumuna İlişkin Sözleşme'nin (1951 Sözleşmesi) 1. maddesinin D, E ve F fikraları ile düzenlenmektedir. 1951 Sözleşmesi'nin D ve E fikralarından farklı olarak, Sözleşmenin 1. maddesinin F fikrası mülteci statüsüne layık olmayan ve bu statüyü hak etmeyen kişilerin mülteci statüsünden hariç bırakılmasını düzenlemektedir. ${ }^{8}$ 1951 Sözleşmesi m. 1 F'de yer alan düzenleme şu şekildedir:

\footnotetext{
BM Güvenlik Konseyi’nin 12 Kasım 2001 günü 4413. oturumunda kabul edilen (2001) 1377 sayılı Kararı, <http://www.un.org/ en/ga/search/view_doc.asp?symbol=S/RES/1377\%20\%282001\%29> erişim tarihi: 5 Şubat 2019 (S/RES/1377 (2001) ).

2 James C. Simeon, 'Complicity and Culpability and the Exclusion of Terrorists from Convention Refugee Status Post-9/11' Refugee Survey Quarterly, Volume 29(4), (2010)s. 105, 106.

3 Geoff Gilbert, 'Exclusion under Article 1F since 2001: Two Steps Backwards, One Step Forward' in V. Chetail and C. Bauloz (eds.) Research Handbook on International Law and Migration. Research Handbooks in International Law, Edward Elgar Publishing, Surrey, 2014, s. 519-540.

4 Monette Zard, ‘Exclusion, ‘Exclusion, terrorism and the Refugee Convention' Forced Migration Review, Volume 32(13), (2002), s. 32 .

5 Simeon, s. 105, 106; Rene Bruin and Kees Wouters, 'Terrorism and the Non-derogability of Non-refoulement' International Journal of Refugee Law, Volume 15(1), (2003), s. 14. Silvia Venier ve Denise Venturi, 'Linking Counter Terrorism and Refugee Law: Unravelling the (Undue) Nexus with International Law' ESIL Conference Paper Series, Volume 10, No 8, (2018), s. 13.

${ }^{6}$ Bu çalışmada 'terörizm ile ilişkisi olan kişiler' terimi, terör suçu failleri, terör örgütü üyeleri, terör örgütüne destek veren, örgüte yeni üye ve yabancı savaşanların katılmasını sağlayan, terör eylemlerini planlayan, azmettiren, gerçekleştiren, terör eylemlerine iştirak eden, finansal ve lojistik destek sağlayan kişiler başta olmak üzere terör örgütü ve eylemleri ile ilişkisi olan tüm kişileri kapsayacak şekilde geniş olarak kullanılmıştır.

7 Convention relating to the Status of Refugees (signed 28 July 1951, entered into force 22 April 1954) 189 UNTS 150 Mültecilerin Hukuki Statüsüne İlişkin Sözleşme 28 Temmuz 1951 tarihinde imzalanmış ve 22 Nisan 1954 yılında yürürlüğe girmiştir.

81951 Sözleşmesinin 1. Maddesinin E ve D fikraları uluslararası korumaya ihtiyaç duymayan kişilerin mülteci statüsünden hariç bırakılmasını düzenlemektedir.
} 
"Bu Sözleşme hükümleri:

(a) barışa karşı suç, savaş suçu veya insanlığa karşı suç gibi suçlar için hükümler koyan uluslararası belgelerde tanımlanan bir suç işlediğine;

(b) mülteci sıfatıyla kabul edildiği ülkeye sığınmadan önce, siğındiğg ülkenin dışında ă̆ır bir siyasi olmayan suç işlediğine;

(c) Birleşmiş Milletler 'in amaç ve ilkelerine aykırı fillerden suçlu olduğuna; dair hakkında ciddi kanaat mevcut olan bir kişi hakkında uygulanmayacaktır."

1951 Sözleşmesi m. $1 \mathrm{~F}$ esas alınarak mülteci statüsünden hariç bırakma hükümleri 2014 yılında yürürlüğe giren Yabancılar ve Uluslararası Koruma Kanunu9 (YUKK) m. 64(c)'de düzenlenmiştir. YUKK m. 64(c)'deki düzenleme şu şekildedir: 'Başvuru sahibi; Sözleşmenin 1 inci maddesinin (F) fikrasinda belirtilen fiillerden suçlu olduğuna dair ciddi kanaat varsa, uluslararası korumadan hariçte tutulur."10 1951 Sözleşmesi m. 1 F’de yer alan mülteci statüsünden hariç bırakmaya ilişkin düzenleme Avrupa Birliği (AB) müktesebatında da yer almaktadır.

2004/83/EC sayılı Avrupa Konseyi Vasıf Yönergesi ile Avrupa Birliği hukukunda kimlere mülteci ve ikincil koruma statüsü verilmesi gerektiğine ve kimlerin bu statülerden hariç tutulması gerektiğine açıklık getirilmiştir. ${ }^{11}$ Avrupa Ortak Sığınma Politikası hedefine ulaşmak amacıyla 2011/95/EU sayılı AB Vasıf Yönergesi (Recast Qualification Directive) 2011 yılında kabul edilmiştir. ${ }^{12}$ 2011/95/EU sayıl1 Yönerge İngiltere ve İrlanda hariç diğer tüm AB üyeleri için 2004/83/EC sayılı Vasıf Yönergesini 22 Aralık 2013 tarihinde yürürlükten kaldırmıştır. ${ }^{13}$ Mülteci statüsünden hariç bırakma 2004/83/EC sayılı Vasıf Yönergesi m. 12 ile daha sonra ise 2011/95/ EU sayılı AB Vasıf Yönergesi m. 12 ile düzenlenmiştir. Bu iki yönergede de hariç bırakılma nedenleri neredeyse aynı şekilde belirlenmiştir. ${ }^{14} 1951$ Sözleşmesi m.

$9 \quad$ R.G $11 / 4 / 2013$, S. 28615

10 Mülteci statüsünden hariç bırakılan kişilerin etkili başvuru hakkı için bkz. Özgenur Yiğit, Uluslararası Hukuk, Avrupa Hukuku ve Türk Hukukunda Mülteci ve Sığınmacıların Etkili Başvuru Hakkı, Onikilevha, 2018, İstanbul.

11 Council Directive 2004/83/EC of 29 April 2004 on minimum standards for the qualification and status of third country nationals or stateless persons as refugees or as persons who otherwise need international protection and the content of the protection granted OJ L 304/12, 30.9.2004. (2004/83/EC sayılı Avrupa Konseyi Vasıf Yönergesi) Başlangıç Hükümleri, para 6.

12 Directive 2011/95/EU of the European Parliament and of the Council of 13 December 2011 on standards for the qualification of third-country nationals or stateless persons as beneficiaries of international protection, for a uniform status for refugees or for persons eligible for subsidiary protection, and for the content of the protection granted OJ L 337, 20.12.2011. (2011/95/ EU sayılı AB Vasıf Yönergesi) Başlangıç Hükümleri, para 8-13.

13 2011/95/EU sayılı AB Vasıf Yönergesi m. 41; 2004/83/EC sayılı Avrupa Konseyi Vasıf Yönergesi ve 2011 Vasıf Yönergesi Danimarka için bağlayıcı değildir.

14 AB Hukukunda uluslararası korumadan hariç bırakma mülteci statüsünden ve ikincil koruma statüsünden hariç bırakmayı kapsamaktadır. İkincil korumadan hariç tutma AB Vasıf Yönergesi m. 17'de şu şekilde düzenlenmiștir: “1.Bir üçüncü ülke uyruklu ya da vatansız bir kişi aşağıdaki hususlarl düşündürecek ciddi nedenler bulunduğu takdirde ikincil korumaya uygunluktan hariç tutulur:

(a) uluslararası belgelerin ilgili hükümlerinde tanımlandığ ş̧ekilde barışa karşı bir suç, bir savaş suçu ya da insanlık suçu işlemişse;

(b) ciddi bir suç işlemişse;

(c) Birleşmiş Milletler Şartının Önsözünde ve 1. ve 2. Maddelerinde yer alan Birleşmiş Milletlerin amaç ve ilkelerine aykırı fiillerden suçlu bulunmușsa.

(d) bulunduğu Üye Devlet'in halkı ya da güvenliği için tehlike oluşturuyorsa.

2.Birinci paragrafta belirtilen suç ya da fillerin işlenmesini tahrik eden veya bunlara başka bir şekilde iştirak eden kişiler de ikinci paragraf hükmüne tabidir.

3. Birinci paragrafin kapsamında olmayan, fakat ilgili Üye Devlet te işlenmiş olsa hapis cezasına tabi olacak bir ya da 
1 F’yi esas alınarak Vasıf Yönergesi m. 12(2) ve (3) ile mülteci statüsünden hariç bırakmayı şu şekilde düzenlenmiştir:

"2. Hakkında aşağıdaki fiilleri işlediğine dair ciddi kanaat mevcut olan üçüncü ülke vatandaşı veya vatansız kişiler mülteci statünden hariç bırakılır:

(a) Kişinin barışa karşı suç, savaş suçu veya insanlığa karşı suç gibi suçlar için hükümler koyan uluslararası belgelerde tanımlanan bir suç işlediğine,

(b)mülteci sıfatıyla kabul edildiği ülkeye sığınmadan önce, sı̆̆ındĭ̆ı ülkenin dişında ă̆ır bir siyasi olmayan suç işlediğine; bu maddedeki 'sı̆̆ınmadan önce' terimi kişiye mülteci statüsüne bağll ikamet izninin verilmesi olarak kabul edilecektir. Ĕger söz konusu suç özellikle zalimane filleri içeriyorsa, politik amaçlar gütse bile 'ağır bir siyasi olmayan suç' olarak kabul edilecektir.

(c) BM Kurucu Andlaşması m. 1 ve 2 ve Giriş bölümünde belirtildiği üzere Birleşmiş Milletler'in amaç ve ilkelerine aykırı fillerden suçlu olduğuna,

3. 2. paragraf yukarıdaki filleri ve suçları azmettiren veya bunlara iştirak eden kişiler için de uygulanir."

Her ne kadar Vasıf Yönergesi m. 12(2) ve (3), 1951 Sözleşmesi m. 1 F’yi esas alınarak hazırlanmış olsa da bu iki düzenleme arasında küçük de olsa bazı farklılıklar bulunmaktadır. 1951 Sözleşmesi ve Vasıf Yönergesinde yer alan mülteci statüsünden hariç bırakma hükümleri arasındaki farklardan bahsetmek gerekirse, Vasıf Yönergesi m. 12 (2)(b)'de, 1951 Sözleşmesi m. 1 F (b)'ye ek olarak 'ağır suç' kavramı ile ilgili olarak zalimce işlenmiş suçlar politik nedenlerde işlenmiş bile olsalar dahi ă̆ır suç sayılacaktır ibaresi yer almaktadır. 1951 Sözleşmesi m. 1 F (b)'de geçen 'ülkeye girişten önce' deyimi Vasıf Yönergesi m. 12(2)(b)'de kişiye mülteci statüsüne bağll ikamet izni verilmesi olarak kabul edilmiştir. Vasıf Yönergesi ayrıca 1951 Sözleşmesi m. 1 F'den farklı olarak Vasıf Yönergesi m. 12 (2)'de geçen suçların sadece faillerinin değil bu suçları ve eylemleri azmettiren ve bunlara iştirak eden kişilerin de mülteci statüsünden hariç tutulacağını düzenlemiştir.

Her ne kadar terörizm, terör örgütü üyeliği ve terör faaliyetlerinde bulunma 1951 Sözleşmesi m. 1 F kapsamında açıkça mülteci statüsünden hariç bırakma nedeni sayılmamış olsa da terör ile ilişkisi bulunan kişilerin mülteci statüsünden hariç bırakılması çoğunlukla 1951 Sözleşmesi m. 1 F (b) ve (c) ve Vasıf Yönergesi m. 12 (2) (b) ve (c) kapsamında incelenmektedir. ${ }^{15}$ Yine de, terörizm, terör örgütüne üyelik ve terör faaliyetlerinde bulunma 1951 Sözleşmesi m. 1 F'de açıkça mülteci

daha fazla suçu Üye Devlet'e kabulünden önce işlemişse veya sadece bu suçların cezasını çekmemek için menşe ülkesini terk etmişse, Üye Devletler bir üçüncü ülke uyruklu ya da vatansız bir kişiyi ikincil korumaya uygunluktan hariç tutabilir." Çeviri için bkz. Egemen Demircioğlu ve Meltem Karatoprak, Iltica ve Göç Mevzuatı, Başkent Matbaası, 2005, Ankara, s. 219. Bu makalenin konusu mülteci statüsünden hariç tutulma ile sınırlı olduğundan makalede ikincil korumadan hariç tutulma konusu incelenmeyecektir.

15 Şunu da belirtmek gerekir ki, terör faaliyetleri eğer barışa karşı suç, insanlığa karşı suç veya savaş suçu kapsamında işlenmişse bu suçları işleyenler 1951 Sözleşmesi m. 1 F (a) ve Vasıf Yönergesi m. 12 (2) (a) kapsamında mülteci statüsünden hariçte bırakılabilir. Ör: savaş suçu kapsamına silahlı çatışma sırasında sivillere yönelik terör amaçlı silahlı saldırı gerçekleştirenler 1951 Sözleşmesi m. 1 F (a) kapsamında hariçte bırakılabilir. Bkz. Sarah Singer, Terrorism and Exclusion from Refugee Status in the UK: Asylum Seekers Suspected of Serious Criminality, Brill/Nijhoff, 2015, Leiden, s. 54, 55. 
statüsünden hariç tutma nedeni olarak sayılmadığ için terör ile ilişkisi olan kişilerin mülteci statüsünden hariç bırakılması konusu birçok yorum sorununu da beraberinde getirmiştir. Avrupa Birliği Adalet Divanı (ABAD) ön karar prosedürü (the preliminary reference procedure) ile verdiği kararlarda terör ve mülteci statüsünden hariç bırakmaya ilişkin önemli sorulara yıllar içerisinde cevap vermiştir.

Avrupa Birliği’nin İşleyişine Dair Andlaşma m. 267 uyarınca Avrupa Birliği Adalet Divanı, Birlik kurum, organ, ofis veya ajanslarının tasarruflarının geçerliliği ve yorumu hakkında ön karar vermeye yetkilidir. ${ }^{16}$ Ön karar prosedüründe amaç $\mathrm{AB}$ müktesebatına ilişkin yorum birliğini ve $\mathrm{AB}$ üyesi tüm devletlerde Birlik hukukunun aynı şekilde yorumlanmasını sağlamaktır. ${ }^{17}$ Ön karar prosedürü, $A B$ üyesi devletlerin ulusal mahkemelerinin önlerine gelen bir uyuşmazlıkta $A B$ Yönergelerine ilişkin yorum sorunları ile ilgili yargılamanın her aşamasında ABAD'a başvurmalarına imkân tanımaktadır. ${ }^{18}$ $A B A D$ 'ın $A B$ Yönergelerinin yorumuna ilişkin verdiği ön kararlar başvuru yapan Üye devlet mahkemelerini bağladığı gibi ayrıca karara konu olan normun yorumu ile ilgili ortaya çıkabilecek gelecekteki uyuşmazlıklar için de geçerli olmaktadır. ${ }^{19}$

Bu makalede Avrupa Birliği Adalet Divanı'nın ön karar prosedürü ile verdiği 9 Kasım 2010 tarih ve C-57/09 ve C-101/09 sayll B ve D Karar120, 24 Haziran 2015 tarih ve C-373/13 sayıl1 T Kararı ${ }^{21}$ ve 31 Ocak 2017 tarih ve C-573/15 sayll Lounani Karar122 incelenmek suretiyle $\mathrm{AB}$ Hukukunda terör ile ilişkisi olan yabancıların mülteci statüsünden hariç bırakılması konusu ele alınacaktır. Bu kararlarda ABAD AB Vasıf Yönergesi m. 12 'de yer alan mülteci statüsünden hariç bırakma hükümlerinin yorumu ve uygulanması bakımından önemli ilkeler getirmiştir. Yukarıda belirtildiği üzere AB Vasıf Yönergesi $\mathrm{m}$. 12 açıkça 1951 Sözleşmesi m. 1 F'ye atıfta bulunmaktadır. Bu nedenle ABAD'ın söz konusu kararları 1951 Sözleşmesi m. 1 F’nin yorumu ve uygulanması ile ilgili önemli bilgiler içermektedir ve 1951 Sözleşmesi m. 1 F ve YUKK m. 64'ün yorumunda dikkate alınabilecek yol gösterici nitelikte kapsamlı, gerekçeli ve önemli kararlardır.

Literatürde, 1951 Sözleşmesi ve YUKK kapsamında mülteci statüsünden hariç bırakılma ve terör örgütü ile ilişkisi olan kişilerin İnsan Haklarını ve Temel Özgürlükleri Koruma Sözleşmesii23 (Avrupa İnsan Hakları Sözleşmesi) m. 3 kapsamında geri gönderilmeden korunmasını konu edinen Türkçe çalışmalar ${ }^{24}$

\footnotetext{
6 Mehmet Hanifi Bayram, Avrupa Birliği Hukuku Dersleri, Seçkin, 3. Baskı, 2018, İstanbul, s. 223.

17 Ahmet M. Güneş, Avrupa Birliği Hukukuna Giriş, Onikilevha, 2. Baskı, 2016, İstanbul, s. 218, 219.

18 Güneş, s. 219, 220, 221.

9 Bayrams. 231, 232.

C-57/09 and C-101/09, Bundesrepublik Deutschland $v$ B and D [2010] ECR I-10979. (Bundan sonra ABAD, B ve D Karar1)

C-373/13, H. T. v Land Baden-Württemberg [2015] ECLI:EU:C:2015:413. (Bundan sonra ABAD, T Karar1)

22 C-573/15, Commissaire général aux réfugiés et aux apatrides v. Mostafa Lounani [2017] ECLI:EU:C:2017:71 (Bundan sonra Lounani Kararı).

23 İnsan Haklarını ve Temel Özgürlükleri Koruma Sözleşmesi, 4 Kasım 1950'de imzalanmış ve 3 Eylül 1953 tarihinde yürürlüğe girmiştir.

24 Nuray Ekşi, Mahkeme Kararları Işı̆ğında Suçluların Ilttica Sistemi Dışında Bırakılması, Beta Yayınevi, 2017, İstanbul; Işı1 Özkan:
} 
mevcut olsa da AB Hukukunda ve ABAD kararları 1şı̆̆ında terör ile ilişkisi olan kişilerin mülteci statüsünden hariç bırakılmasını konu edinen çok az sayıda Türkçe akademik çalışma bulunmaktadır. ${ }^{25} \mathrm{Bu}$ makalenin amacı ABAD kararları 1şı̆̆ında terör ile ilişkisi olan kişilerin mülteci statüsünden hariç bırakılması konusunu ele almak suretiyle literatüre katkıda bulunmaktır.

Makalenin ilk bölümünde ABAD'ın terör örgütüne üye olan, terör faaliyetinde bulunan ve bu faaliyetlere destek veren kişilerin mülteci statüsünden hariç bırakılması ve ikamet izninin iptaline ilişkin üç kararı özetlenecek ve analiz edilecektir. Makalenin ikinci kısmında ise bu analizden hareket edilerek terör ile ilişkisi olan kişilerin mülteci statüsünde hariç bırakılmasına ilişkin ABAD tarafından ortaya konulmuş ilkeler belirlenecektir.

\section{Avrupa Birliği Adalet Divanı’nın Terör Örgüttï ile İlişkisi Olan Kişilerin Mülteci Statüsünden Hariç Bırakılması İle İlgili Verdiği Kararlar}

Avrupa Birliği Adalet Divanı'nın 2004/83/EC sayılı Vasıf Yönergesi m. 12(2) kapsamında terörizm ve mülteci statüsünden hariç bırakmaya ilişkin ön karar prosedürü ile verdiği ilk karar, 9 Kasım 2010 tarih ve C-57/09 ve C-101/09 sayıl1 B ve D Kararı'dır. Mahkemenin terör, ulusal güvenlik ve mülteci statüsünden hariç bırakmaya ilişkin içtihadının son yıllarda ne ölçüde değiştiğinin ortaya konulması açısından bu karar bir başlangıç noktası teşkil etmektedir.

\section{A. 9 Kasım 2010 tarih ve C-57/09 ve C-101/09 sayılı B ve D Kararı}

$B$ ve D Kararı iki ön karar talebinin birleştirilmesi ile görülmüştür. Alman Federal Mahkemesi'nin temyiz aşamasında incelediği C-57/09 sayılı ön karar başvurusunda, 1975 doğumlu Türk vatandaşı B, öğrenciliğinden beri Dev Sol'un (şimdiki DHKP/C) sempatizanı olduğunu ve 1993-1995 yılları arasında örgüt üyesi olarak dağda silahlı çatışmalara katıldığını belirtmiştir. ${ }^{26} 1995$ yılında Türkiye' de yakalanan B yakalandığı süreçte ciddi bedensel zarara uğradığını ve işkence ile ifadesinin alındığını iddia etmiştir. ${ }^{27}$ B, 1995 yılında Türkiye'de ömür boyu hapis cezasına çarptırılmış, 2001 yılında diğer bir mahkûmu öldürmüş ve bu nedenle B'ye ikinci bir müebbet hapis cezası verilmiştir. ${ }^{28} 2002$ yılında sağlık nedeni ile 6 ay süreyle şartlı salıverilen B, Almanya'ya kaçarak 2002 yılında burada sı̆̆ınma talebinde

Göç, İtica ve Slğınma Hukuku, 2. Baskı, Seçkin, 2017, Ankara, s. 110-113, 178-185; Döndü Kuşçu, Yabancılar ve Uluslararası Koruma Kanunu Hükümleri Uyarınca Yabancıların Sınır Dışı Edilmeleri, Onikilevha, 2017, İstanbul; Bülent Çiçekli, 6458 Sayll Kanunla Güncellenmiş Yabancılar ve Mülteciler Hukuku, 6. Baskı, Seçkin Yayınevi, 2015, Ankara, s. 257-262.

25 Nuray Ekşi Mahkeme Kararları Ișı̆̆ında Suçluların İltica Sistemi Dışında Bırakılması adlı eserinde 9 Kasım 2010 tarih ve C-57/09 ve C-101/09 sayılı B ve D Kararı ve 31 Ocak 2017 tarih ve C-573/15 sayılı Lounani Kararına yer vermiştir. Bkz Ekşi, s.118-123,138-140.

26 ABAD, B ve D Kararı, para 44.

27 ibid, para 45.

28 ibid, para 47, 48. 
bulunmuştur. İltica ve göç alanında Alman yetkili mercii olan Alman Göç ve İltica Dairesi B'nin başvurusunu 1951 Sözleşmesi m. 1 F (b)'de yer alan ağır bir siyasi olmayan suç işlediğinden bahisle reddetmiş ve Türkiye'ye sınır dışı edilebileceğine karar vermiştir. ${ }^{29}$ Gelsenkirchen İdare Mahkemesi bu kararı iptal etmiş ve dava son olarak Alman Federal İdare Mahkemesi'nin önüne gelmiştir. ${ }^{30}$

C-101/09 sayıl1 ön karar isteminde bulunan Alman Federal Mahkemesi'nin incelediği temyizde ise 1968 doğumlu Türk vatandaş1 D, 2001 yılında Almanya’ya gelerek sığınma talebinde bulunmuştur. ${ }^{31}$ Başvurusunu desteklemek için D, 1990 yılında, PKK'ya katılmak için dağa çıktığını, dağda silahlı çatışmalara katıldığını, 1988 'in sonunda, PKK'nın onu Kuzey Irak'a gönderdiğini belirtmiş̧tir. ${ }^{32}$ Ayrıca D, PKK'nın üst düzey yetkililerinden biri olduğunu, Mayıs 2000'de yönetimle ilgili fikir ayrılığı yaşadığı PKK'dan ayrıldığını ve Kuzey Irak'ta bir yıl daha kaldığını, orada güvende hissetmediği için Almanya'ya geldiğini ifade etmiştir. ${ }^{33}$ Alman yetkili mercii 2001 yılında D’ye mülteci statüsü vermiş, Almanya'da yeni terör yasalarının yürürlüğe girmesinden sonra ise D'nin mülteci statüsü 1951 Sözleşmesi m. 1 F (b) ve (c)'de yer alan ağır bir siyasi olmayan suç işlediğinden ve Birleşmiş Milletler'in amaç ve ilkelerine aykırı fillde bulunduğundan bahisle iptal edilmiştir. ${ }^{34} 2005$ yılında Gelsenkirchen İdare Mahkemesi bu kararı iptal etmiş ve dava son olarak Alman Federal İdare Mahkemesi'nin önüne gelmiştir. ${ }^{35}$

Alman Federal İdare Mahkemesi ABAD’a şu soruları yönelmiştir:

"1-Aşağıdaki durumlar 2004/83/EC sayll Vasıf Yönergesi m. 12 (2) (b) ve (c) uyarınca, Birleşmiş Milletler'in amaç ve ilkelerine aykırı bir fil ve ă̆ır bir siyasi olmayan suç teşkil eder mi?

-Bir siğınmacının 2001/931 sayll Ortak Pozisyon Belgesi'nin ${ }^{36}$ ekinde yer alan terörist yöntemleri kullanan kişiler, gruplar ve kuruluşlar listesindeki bir terör örgütüne üye olması ve bu örgütün silahlı eylemlerini aktif olarak desteklemiş olması, (C-57/09 sayll ilk ön karar başvurusunda söz konusu olduğu gibi)

-Bir sığınmacının PKK gibi 2001/931 sayll Ortak Pozisyon Belgesi'nin ekinde yer alan ve bir devlete (ki bu olayda söz konusu devlet Türkiye'dir) karşı yürüttüğü silahlı çatışmada sürekli olarak terör yöntemleri kullanan bir örgütte yıllarca savaşan olarak yer almış ve bu örgütün yönetim kadrosunda önemli bir pozisyonda görev almış olmasl, (C-101-09 sayılı ilk ön karar başvurusunda söz konusu olduğu gibi)

2- Eğer 1. sorunun cevabı olumlu ise, bir kişinin 2004/83/EC sayılı Vasıf Yönergesi m. 12 (2)

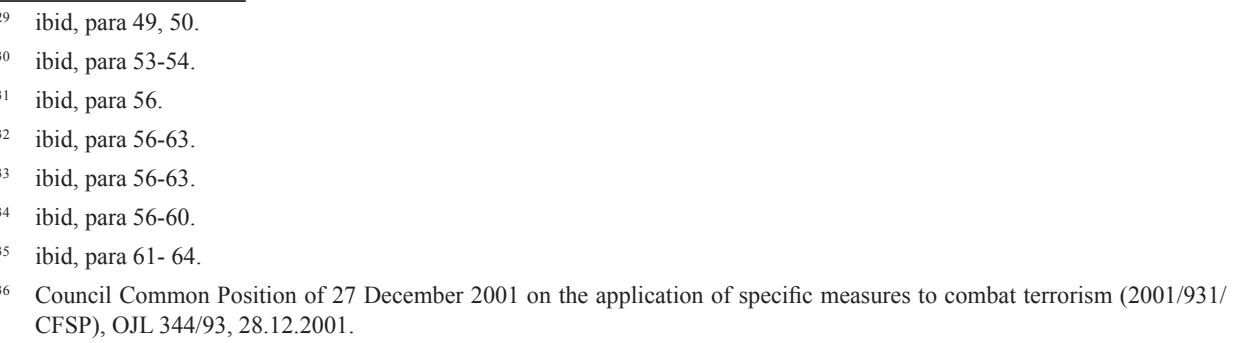


(b) ve (c) uyarınca mülteci statüsünden hariç tutulabilmesi için yabancının halen bulunduğu devlete karşı bir tehdit oluşturmaya devam etmesi gerekli midir?

3- Eğer 2. sorunun cevabı olumsuz ise, bir kişinin 2004/83/EC sayıl Vasıf Yönergesi m. 12

(2) (b) ve (c) uyarınca mülteci statüsünden hariç tutulabilmesi için 'orantılık testi' yapılması gerekli midir?" ${ }^{37}$

$\mathrm{ABAD}, \mathrm{B}$ ve $\mathrm{D}$ Kararında terör örgütü üyelerinin mülteci statüsünden hariç bırakılması ile ilgili önemli bazı hususları açığa kavuşturmuştur. Mahkeme ilk soruya ilişkin olarak, terör eylemlerinin doğaları gereği sivil halkı hedef alan şiddet hareketleri olduğunu ve bu nedenle terör eylemlerinin politik bir amaç gütse dahi 2004/83/EC sayılı Vasıf Yönergesi m. 12(2)(b) kapsamında ağır bir siyasi olmayan suç sayılabileceğini belirtmiştir. $^{38}$ ABAD ayrıca, 2004/83/EC sayılı Vasıf Yönergesinin Giriş Kısmına atıfta bulunarak ${ }^{39}$ Birleşmiş Milletler'in amaç ve ilkelerine aykırı fiillerin hem BM Kurucu Anlaşması hem de BM Güvenlik Konseyi'nin terörle mücadeleye ilişkin kararları 1şı̆ğnda belirlenebileceğini ifade etmiştir. ${ }^{40}$ Bunun ardından, Mahkeme “Güvenlik Konseyi, terör eylemlerinin, yöntemlerinin ve uygulamalarının Birleşmiş Milletler Örgütü'nün amaç ve ilkelerine aykırı olduğunu ve terörist eylemlere malî kaynak să̆lanmasl ve örgütlenmesinin ya da bu nev'i eylemlere azmettirmenin de aynı şekilde Birleşmiş Milletler Örgütü'nün amaç ve ilkelerine aykırı olduğunu ilân eder " ibaresini içeren Eylül 2001 tarihli 1373 sayılı BM Güvenlik Konseyi Karar1 ${ }^{41}$ ve Kasım 2001 tarihli ve 1377 Sayılı Birleşmiş Milletler Güvenlik Konseyi Kararı'na² atıfta bulunarak uluslararası terör eylemlerinin genellikle Birleşmiş Milletler'in amaç ve ilkelerine aykırı olduğunu tespit etmiştir. ${ }^{43} \mathrm{Bu}$ tespit 1 şığında ABAD, 2001/931 sayılı Ortak Pozisyon Belgesi'nin ekindeki terörist yöntemleri kullanan kişiler, gruplar ve kuruluşlar listesinde yer alan bir örgüte üye olmanın uluslararası nitelikli terör faaliyetine katılma anlamına gelebileceğini belirtmiştir. ${ }^{44}$ Kararda ABAD açıkça terör, terör örgütü ve terör örgütü üyesi kavramlarını tanımlamamakla birlikte bu kavramları 2001/931 sayılı Ortak Pozisyon Belgesi ve Eki 1şı̆̆ında yorumlamıştır. ${ }^{45}$

41 BM Güvenlik Konseyi'nin 28 Eylül 2001 günü 4385. oturumunda kabul edilen (2001) 1373 sayılı Kararı, <http://www. un.org/en/ga/search/view doc.asp?symbol=S/RES/1373\%20\%282001\%29>, erișim tarihi: 5 Șubat 2019 (S/RES/1373 (2001) ) para 5. Bu kararda ayrıca "BM Güvenlik Konseyi, mülteci statüsü vermeden önce, slğınma talebinde bulunanların terörist eylemleri örgütlemediği ya da bunları ișlemediğine ve bunlara katılmadı̆̆ına kesin olarak kanaat getirilmesi amacıyla, insan haklarına iliş̧kin uluslararası normlar da dahil olmak üzere, ulusal mevzuatlarındaki geçerli düzenlemeler ve uluslararası hukuka uygun olarak gereken önlemlerin alınmasın talep eder.” ibaresi de yer almaktadır.

42 BM Güvenlik Konseyi’nin 12 Kasım 2001 günü 4413. oturumunda kabul edilen (2001) 1377 sayılı Kararı, <http://www. un.org/en/ga/search/view_doc.asp?symbol=S/RES/1377\%20\%282001\%29> erişim tarihi: 5 Şubat 2019 (S/RES/1377 (2001)).

43 ABAD, B ve D Kararı, para 83.

44 ibid, para 86.

45 Anna Magdalena Kosinska, 'The Problem of Exclusion from Refugee Status on the Grounds of Being Guilty of Terrorist Acts in the CJEU Case-law’ European Journal of Migration and Law, Volume 19(4), (2017), s. 434.
} 
$\mathrm{ABAD}$, terör örgütüne üye olmanın kişiyi mülteci statüsünden doğrudan (otomatik olarak) hariç bırakmayacağını belirtmiş̧ir. ${ }^{46}$ Bununla birlikte Mahkeme her kişi için ayrı ayrı yapılacak bireysel bir değerlendirme sonucunda söz konusu kişinin terör örgütü üyeliği kapsamında ağır bir siyasi olmayan suç veya Birleşmiş Milletler'in amaç ve ilkelerine aykırı bir fiil işlediğine, bunları azmettirdiğine veya bunlara iştirak ettiğine dair ciddi emarelerin var olması durumunda ancak kişinin 2004/83 sayılı Vasıf Yönergesi m. 12(2)(b)(c) ve 12(3) uyarınca mülteci statüsünden hariç bırakılabileceğini belirtmiştir. ${ }^{47}$ Bununla birlikte $\mathrm{ABAD}$, ön karar istemine konu olan davalardaki B ve D'nin üye olduğu örgütlerin PKK ve DevSol (DHKP/C) olduğunu ve bu örgütlerin 2001/931 sayılı Ortak Pozisyon Belgesi Eki'nde yer almasının örgütün eylemleri ve bu örgütler ile terör ile ilişkisi hakkında fikir verdiğini, bu hususun da hariçte bırakmaya ilişkin değerlendirmede dikkate alınabileceğini belirtmiştir. ${ }^{48}$

$\mathrm{ABAD}$, ayrıca terör örgütü üyelerinin mülteci statüsünden hariç bırakılmasına ilişkin olarak yapılacak bireysel değerlendirmede kişinin bu örgütün eylemlerindeki sorumluluğunun araştırılması gerektiğine dikkat çekmiştir. ${ }^{49}$ Mahkeme bu değerlendirmede şu ölçütlerin değerlendirilmesi gerektiğini belirtmiştir:

a) kişinin hariçte bırakmayı gerektirecek eylemlerin işlenişinde oynadığ gerçek rol,

b) kişinin örgütteki rütbesi/derecesi,

c) kişinin örgütün eylemleri ile ilgili sahip olduğu bilgi veya sahip olduğunu sandığ 1 bilgi ve

d) kişinin örgüte üye olmasında ve terör faaliyetlerine katılmasında herhangi bir baskının veya iradesini sakatlayan bir halin etkili olup olmadığ ${ }_{1}{ }^{50}$

Kendisine yönlendirilen ikinci soruya ilişkin olarak, $\mathrm{ABAD}$ bir terör örgütü üyesinin bulunduğu devletin güvenliğine halen devam eden bir tehdit oluşturup oluşturmadığının Vasıf Yönergesi m. 12 kapsamında yapılacak hariçte bırakmaya ilişkin değerlendirmede önemli olmadığını ve bu hususun dikkate alınmasına gerek olmadığını belirtmiştir. ${ }^{51}$ Bununla birlikte, Mahkeme ulusal güvenliğe karş1 tehdit oluşturup oluşturmamaya ilişkin hususun Vasıf Yönergesinin ikincil koruma statüsünden hariçte bırakmayı düzenleyen $\mathrm{m} .17$ ve mülteci statüsünün geri alınması, sona erdirilmesi ve yenilenmemesini ilgilendiren m. 14 kapsamında dikkate alınabileceğini tespit etmiştir.

Kendisine yönlendirilen üçüncü soruya ilişkin olarak, ABAD bir kişinin 2004/83/

\footnotetext{
ABAD, B ve D Kararı, para 89, 92, 94; Ekşi s. 120, 122; Venier ve Venturi, s. 17.

47 ABAD, B ve D Kararı, para 94.

48 ibid, para 90.

49 ibid, para 95,99 .

s0 ibid, para 96, 97.

51 ibid, para 105.
} 
EC sayılı Vasıf Yönergesi m. 12 (2) uyarınca mülteci statüsünden hariç tutulabilmesi için 'orantılık testi' yapılmasının gerekli olmadığına karar vermiştir. ${ }^{52}$ Gerekçe olarak da Mahkeme, bir kişinin mülteci statüsünden hariç bırakılmasının doğrudan kişinin sınır dışı edileceği anlamına gelmediğini bu nedenle, kişinin sınır dışı edilip edilemeyeceğine ilişkin değerlendirmenin mülteci statüsünden hariç birakmaya ilişkin değerlendirmeden farklı olduğunu ve bu değerlendirmeden ayrı şekilde yapılması gerektiğini belirtmiştir. ${ }^{53}$

\section{B. 24 Haziran 2015 tarih ve C-373/13 sayılı T Kararı}

ABAD'a ön karar için başvuran Baden-Württemberg İdare Mahkemesi'nin gördüğü davada, Almanya’da 1993 yılında mülteci statüsünü kazanmış Kürt asıllı bir Türk vatandaşı olan T'nin süresiz ikamet izni, PKK için bağış topladığının ve örgüt toplantılarına katıldığının Alman Mahkemeleri tarafından tespit edilmesi üzerine iptal edilmiş ve bu iptal dava konusu yapılmıştır. ${ }^{54}$ T'nin ikamet izni iptal edilmiş olsa da hakkındaki sınır dışı kararının uygulanması Almanya'daki aile bağları ve mülteci statüsünün devamı nedeniyle askıya alınmıştır. ${ }^{55}$ ABAD’ın T Kararı, mülteci statüsüne sahip bir kişinin terör örgütüne destek vermesinin, 2004/83/EC sayılı Vasıf Yönergesinin m. 24 uyarınca süresiz ikamet izninin iptali için geçerli bir neden sayılıp sayılamayacağına ve kişinin Vasıf Yönergesinin m. 21 uyarınca geri gönderme yasağının kapsamı dışında kalıp kalmadığına ilişkindir. ${ }^{56}$

Vasıf Yönergesi m. 24'de: “Üye Devletler mülteci statüsü sahiplerine statülerinin tanınmasını izleyen mümkün olan en kısa zaman içinde en az 3 yıl süreli ikamet izni verecek ve ulusal güvenlik ve kamu düzenine dair geçerli nedenler olmadiğl sürece ve Yönerge'nin 21(3) maddesi sakl kalmak şartıyla bu izni yenileyecektir.” hükmü yer almaktadır. Vasıf Yönergesi m. 21 ise şu düzenlemeyi içermektedir:

“1. Üye Devletler, uluslararası yükümlülüklerine uygun olarak geri göndermeme (nonrefoulement) ilkesine saygl gösterecektir.

2. 1. paragrafta belirtilen uluslararası yükümlülükler tarafindan yasaklanmamış olması şartıyla, Üye Devletler, aşağıdaki durumlarda bir mülteciyi statüsü resmi olarak tanınmış olsun ya da olmasin, geri gönderebilir:

(a) Bulunduğu Üye Devletin güvenliği için tehlikeli sayılması yolunda ciddi sebepler bulunan,

(b) Özellikle ciddi bir adi suçtan dolayı kesinleşmiş bir hükümle mahkûm olduğu için Üye Devletin halkı açısından bir tehlike oluşturan,

3. Üye Devletler, 2. paragrafin geçerli olduğu durumlarda mültecilerin ikamet iznini geri alabilir, sona erdirebilir, reddedebilir veya yenilenmeyebilir."

\footnotetext{
ibid, para 111.

ibid, para 110.

ABAD, T Kararı, para 27-38

ibid, para 27-38.

6 ibid, para 39.
} 
Mahkeme ilk olarak, hem Vasıf Yönergesi m. 21 hem de m. 24 kapsamında Üye devletlerin yabancıların ikamet izinlerini iptal edebileceklerini fakat iptal nedenleri bakımından geri gönderme yasağını düzenleyen Vasıf Yönergesi m. 21 ve ikamet izninin iptalini düzenleyen m. 24. arasında ayrıma gidilmesi gerektiğini ortaya koymuştur. ${ }^{57}$

Yukarıda görüldüğü üzere mültecilerin geri gönderilmesini düzenleyen Vasıf Yönergesinin 21. maddesinde, bulunduğu ülkenin güvenliği için tehlikeli sayılan ve tehlikeli sayılması yolunda ciddi sebepler bulunan bir mültecinin Üye ülkenin uluslararası hukuktan kaynaklanan sorumluluklarına aykırı olmamak şartıyla başka bir ülkeye gönderilebileceği düzenlenmiştir. Mahkeme, ancak mültecinin bir ülkeye geri gönderilmesi uluslararası insan hakları hukukundaki geri göndermeme prensibine aykırı olmayacaksa, ikamet izninin Vasıf Yönergesi m. 21 uyarınca iptal edilebileceğini belirtmiştir. Mahkeme bunun yanı sıra Vasıf Yönergesi m. 21 uyarınca bir mültecinin başka bir ülkeye gönderilmesinin sonuçlarının çok ağır olduğunu ve bu madde kapsamında geri göndermenin ülkenin güvenliğini sağlamak için son çare olarak uygulanması gerektiğini belirtmiştir. ${ }^{58}$ Buna karşın Mahkeme Vasıf Yönergesi m. 24'te yer alan ikamet izni iptali ile ilgili olarak, bir mültecinin ikamet izninin iptalinin mülteci statüsünden hariçte bırakma ve kişinin sınır dışı edilmesi sonucunu doğurmadığını ve bu nedenle Vasıf Yönergesi m. 24'te yer alan 'ulusal güvenlik ve kamu düzenine dair geçerli bir neden' kavramının m. 21 'de belirtilen 'Üye devletin güvenliği için bir tehlike teşkil ettiğine dair ciddi bir neden' kavramına göre daha geniş ve esnek şekilde yorumlanabileceğine karar vermiştir. ${ }^{59}$

ABAD'a T Kararında yöneltilen bir diğer soru da, bir kişinin terör örgütüne destek vermesinin o kişinin ikamet izninin iptali için Vasıf Yönergesi m. 24 uyarınca 'ulusal güvenlik ve kamu düzenine ilişkin geçerli bir neden’ sayılıp sayılamayacağına ilişkin idi. ${ }^{60}$ Mahkeme bu soruya olumlu bir cevap vermiştir. ${ }^{61}$ Mahkeme Vasıf Yönergesi m. 24'te geçen ulusal güvenlik ve kamu düzenine dair geçerli bir neden kavramını açıklamak için AB Vatandaşlık Yönergesinin ${ }^{62} 28$. maddesinde geçen kamu güvenliği kavramına atıfta bulunmuştur. ${ }^{63} \mathrm{ABAD}$, kamu güvenliği kavramının hem ülkenin iç hem de dış güvenliği ile ilgili olduğunu ve kamu kurumları ve temel

\footnotetext{
ibid, para 50; Steve Peers, 'What if a refugee allegedly supports terrorism? The CJEU judgment in T' EU Law Analysis, 24 Haziran 2015, < http://eulawanalysis.blogspot.com/2015/06/what-if-refugee-allegedly-supports.html> erişim tarihi: 5 Şubat 2019

58 ABAD, T Karar1, para 71, 72.

59 ibid, para 73, 74.

60 ibid, para 56.

61 ibid, para 100.

${ }_{62}$ Directive 2004/38/EC of the European Parliament and of the Council of 29 April 2004 on the right of citizens of the Union and their family members to move and reside freely within the territory of the Member States amending Regulation (EEC) No 1612/68 and repealing Directives 64/221/EEC, 68/360/EEC, 72/194/EEC, 73/148/EEC, 75/34/EEC, 75/35/EEC, 90/364/EEC, 90/365/EEC and 93/96/EEC (Text with EEA relevance) OJ L 158, 30.4.2004.

${ }^{63}$ ABAD, T Kararı, para 77, 78.
} 
kamu hizmetlerinin işleyişine ve toplumun olağan şekilde yaşamını sürdürebilmesine karşı tehditlerin ve uluslararası ilişkilere veya devletlerin barışçıl şekilde birlikte var olmasına veya bir devletin askeri çıkarlarına yönelik ciddi risklerin kamu güvenliği kapsamında değerlendirilebileceğini tespit etmiştir. ${ }^{64}$ Mahkeme bu husus 1şı̆̆ında, bir üçüncü ülke vatandaşının uluslararası terörizmi destekleyen bir örgüte üye olmasının veya bu örgüt faaliyetlerini desteklemesinin açık olarak ulusal güvenliği ve kamu düzenini ilgilendirdiğini ifade etmiştir. ${ }^{65}$

ABAD, Vasıf Yönergesi m. 24 kapsamında yapılacak değerlendirmede kişinin destek verdiği veya üyesi olduğu terör örgütünün eylemlerinin ulusal güvenlik veya kamu düzenine zarar verebilecek nitelikte olup olmadığının belirlenmesi gerektiğini ifade etmiştir. ${ }^{66}$ Mahkeme ayrıca söz konusu davada T'nin PKK'ya destek verdiği, bu örgütün 2001/931 say1lı Ortak Pozisyon Belgesi'nde geçen bir terör örgütü olduğu ve bunun kişinin desteklediği örgütün eylemlerinin ulusal güvenlik veya kamu düzenine zarar verebilecek nitelikte olup olmadığına dair değerlendirmede dikkate alınması gerektiğini tespit etmiştir. ${ }^{67}$ Mahkeme ayrıca PKK gibi bir terör örgütüne destek vermenin Vasıf Yönergesi m. 24 kapsamında bir mültecinin ikamet iznini iptal etmek için yeterli bir neden teşkil edebileceğini belirtmiştir. ${ }^{68}$ Bununla birlikte, ABAD terör örgütüne destek vermenin otomatik olarak ikamet izni iptalini beraberinde getirmeyeceğini, Vasıf Yönergesi m. 24 uyarınca bir mültecinin ikamet izninin iptaline ilişkin kişinin üye olduğu veya destek verdiği örgütün faaliyetleri ve mültecinin şahsi eylemlerinin de dikkate alınarak bireysel bir değerlendirme yapılması gerektiğini belirtmiştir. ${ }^{69}$ Mahkeme kişinin terör ile ilişkili faaliyetleri nedeniyle ikamet izninin iptaline ilişkin yapılacak değerlendirmede şu hususların dikkate alınması gerektiğine karar vermiştir:

“-Kişinin örgüte ne şekilde destek verdiği,

-kendisinin terör eylemlerine katılıp katılmadiğı,

-terör eylemlerinin planlanmasl, gerçekleştirilmesi ve bu eylemlere karar verilmesinde nasıl bir rol oynadı̆̆

- terör eylemlerinin finansmanında nasıl bir rol oynadı̆̆ı,

- terör örgütü eylemlerine ne şekilde ve ne ölçüde kaynak sağladı̆̆ ${ }^{\prime} .{ }^{70}$

ABAD, dava dosyasından T şahsının PKK'nın hukuka aykırı nitelikte olmayan toplantılarına ve Kürt yeni yılı için düzenlenen toplantılara katılmasının ve PKK örgütü için bağış toplamasının söz konusu olduğunu, bu faaliyetlerin kendi içinde

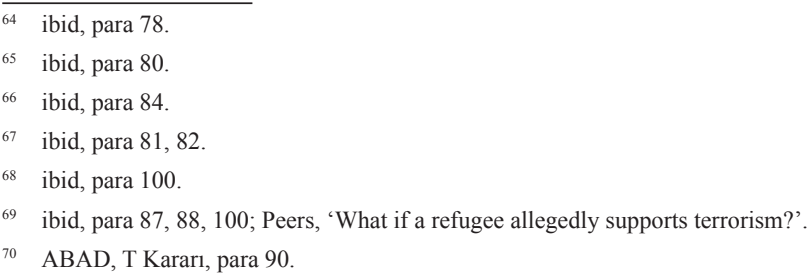


terör eylemi oluşturmadığını belirtmiştir. Mahkeme ayrıca T’nin bu eylemleri gerçekleştirmesinin illa ki PKK'nın terör faaliyetlerinin meşruluğunu desteklediği anlamına gelmeyeceğini de dile getirmiştir. ${ }^{71} \mathrm{Bu}$ husus 1şı̆̆ında, ABAD, Vasıf Yönergesi m. 24 kapsamında yapılacak değerlendirmede, Üye devlet mahkemelerinin T'nin Almanya'nın ulusal güvenliğine ve kamu düzenine ciddi bir tehlike oluşturup oluşturmadığı ve bu tehlikenin hala devam edip etmediği hususlarını değerlendirmesinin gerekli olduğunu ifade etmiştir. ${ }^{72}$

$\mathrm{Bu}$ kararın değerlendirilmesine geçmek gerekirse, ABAD'ın T Kararı özellikle ikamet izninin iptaline ilişkin olarak bireysel bir değerlendirme yapılmasının gerekliliği üzerinde durması bakımından B ve D Kararı'nı takip etmektedir. ${ }^{73}$ Aynı şekilde B ve D Kararında benimsenen mülteci statüsünden hariç bırakmaya ilişkin değerlendirmede dikkate alınması gereken kriterlerin büyük bir çoğunluğu ikamet izninin iptaline ilişkin değerlendirme de dikkate alınacaktır. Fakat, Singer'ın da belirttiği üzere, B ve D Kararından farklı olarak ABAD bu kararda, kişinin örgütün eylemleri ile ilgili sahip olduğu bilgi veya sahip olduğunu sandığı bilginin önemli olduğuna değinmemiştir. ${ }^{74}$

Mahkeme, B ve D Kararından farklı olarak T Kararında kişinin terör örgütüne üyeliğinin ve terör faaliyetlerine katılmasının özgür iradesinin sonucu mu yoksa herhangi bir baskı veya iradeyi sakatlayan halin sonucu mu olduğuna ilişkin bir araştırmanın yapılmasının gerekliliğine de değinmemiştir. ${ }^{75} \mathrm{~B}$ ve $\mathrm{D}$ Kararının konusunun terör örgütüne üyelik nedeniyle mülteci statüsünden hariçte bırakma, $\mathrm{T}$ Kararının konusunun ise terör örgütünü destekleme nedeniyle ikamet izni iptali olduğunu dikkate aldığımızda, hariçte bırakmaya ilişkin değerlendirmenin daha kapsamlı ve detaylı şekilde yapılması çok da şaşırtıcı değildir.

ABAD'ın bir kişinin terör örgütünün toplantılarına katılması ve örgüt için bağış toplamasının illa ki o terör örgütünün ve faaliyetlerinin meşruluğunu desteklediği anlamına gelmeyeceği görüşü kanımızca eleştirilebilir niteliktedir. PKK'nın özellikle sivil ölüm ve yaralanmalarına neden olan terör faaliyetleri herkesçe bilinmektedir. Bu husus 1şığında T, PKK terör örgütünün bir üyesi olmasa ve örgütün terör eylemlerine doğrudan katılmasa bile T'nin PKK için para toplaması ve örgüt toplantılarına katılması bu kişinin açıkça örgütün eylemlerini meşru bulduğu ve örgütün terör faaliyetlerine yardım etmek istediği anlamına gelmektedir. Bu husus ABAD tarafından T Kararında gözden kaçırılmıştır.

71 ibid, para 91.

72 ABAD, bu değerlendirmede, özellikle T'nin PKK'nın terör eylemlerindeki sorumluluğunun ve orantılllik prensibinin dikkate alınması gerektiğini de belirtmiştir. ibid, para 92.

73 Peers, 'What if a refugee allegedly supports terrorism?'; Thomas F. Lampert, 'Prioritizing National Security at the Expense of Refugee Rights: The Effects of HT v. Land Baden-Wurttenberg' Boston College International \& Comparative Law Review, Volume 40, (2017) s. 26.

74 Sarah Singer, 'The War on Terror \& Refugee Law' in S. Juss (edn) Research Handbook on International Refugee Law, Edward Elgar Publishing, forthcoming, s. 11-13. (gelecekte yayınlacak eser yazarın kütüphanesinde yer almaktadır).

75 ibid. 


\section{31 Ocak 2017 tarih ve C-573/15 sayılı Lounani Kararı}

Fas vatandaşı Mustafa Lounani 2006 y1lında Brüksel Ceza Mahkemesi tarafindan Fas İslami Savaş̧̧ Grubu (Groupe Islamique Combattant Marocain) ${ }^{76}$ adlı uluslararası terör örgütünün Belçika ayağında terör eylemlerine katıldığı, bu örgütün önde gelen kişilerinden olduğu ve örgüt üyeliği kapsamında sahte belge hazırladığından bahisle terör örgütüne üyelik suçundan hüküm giymiş ve 6 yıl hapis cezası ile cezalandırılmıştır. ${ }^{77}$ Mustafa Lounani 2010 yılında Belçika'da mülteci statüsüne başvurmuş, bu başvurusu 1951 Sözleşmesi m. 1 F (c) kapsamına girdiğinden bahisle reddedilmiştir. ${ }^{78}$ Kararın temyizi sonrasında dava Belçika Danıştayı'nın önüne gelmiş ve bu davaya ilişkin ön karar istemiyle Belçika Danıştayı ABAD’a 2004/83 sayılı Vasıf Yönergesi’nin mülteci statüsünden hariç bırakılmayı düzenleyen 12. maddesi ile ilgili birtakım önemli sorular yöneltmiştir.

Belçika Danıştayı ABAD’a ilk olarak “2004/83/EC sayll Vasıf Yönergesi m. 12(2)(c)'de yer alan hariç birakılma hükmünün uygulanabilmesi için 2002/475 sayılı Konsey Çerçeve Kararı m.1(1)'de geçen terör suçlarından birinden veya birden fazla terör suçundan hüküm giyilmiş olmasının zorunlu olup olmadığına" ilişkin bir soru yöneltilmiştir. ${ }^{79}$ Davada adı geçen terörle mücadeleye ilişkin 13 Haziran 2002 tarihli ve 2002/475/JHA sayılı Konsey Çerçeve Karar ${ }^{80}$ Avrupa Birliği’nin terörle mücadele politikasının temelini oluşturmaktadır. Bu Karar ile Birlik üyelerinin uyumlaştırılmış terör suçu tanımını kabul etmesi ve terörle mücadele ile ilgili ortak bir yasal çerçeve oluşturulması öngörülmüştür. ${ }^{81}$ Terörle Mücadeleye ilişkin 2002/475/JHA sayılı Çerçeve Kararı'nın 1. maddesi terör suçlarını şu şekilde tanımlamaktadır:

"Bir devlete veya uluslararası örgüte ciddi bir zarar vermeye yönelik,

-toplumu ciddi şekilde korkutma veya,

-bir devlet yönetimini veya uluslararası örgütü bir eylemi yapmaya veya yapmamaya zorlama, veya

- bir devletin veya uluslararası örgütün temel siyasi, anayasal, ekonomik ve sosyal yapısın esasl şekilde bozmaya veya ortadan kaldırma amacı güden,

a) Öldürme,

b)Kişinin beden bütünlüğüne yönelik saldırl,

c) Kaçırma ve rehin alma,

d) Bir devlete veya kamu malına, ulaşım sistemine, dijital ve haberleşme sistemleri de dahil olmak üzere altyapı sistemlerine, kıta sahanlı̆̆ında bulunan sabit platformlara, kamuya açık yerlere veya özel mülkiyete, hayat kaybı veya ağır ekonomik zarar verebilecek nitelikte ciddi zarar verme,

\footnotetext{
Söz konusu terör örgütünün Türkçe çevirisi için bkz. Ertan EFEGIL, Radikal Yoruma Dayalı Dini Terör Örgütlerinin Incelenmesi, Gündoğan Yayınları, 2018, İstanbul, s. 125.

7 Lounani Kararı, para 29.

ibid, para 31.

9 ibid, para 39.

80 Council Framework Decision of 13 June 2002 on combating terrorism OJ L 164, 22.6.2002, p. 3-7.

81 ibid, Giriş, para 2.
} 
e)Hava aracl, gemi ve diğer kamu ve özel taşıma araçlarına el koyma,

f)Silah, patlayıcı, nükleer, biyolojik veya kimyasal silah üretme, zilyetliğinde bulundurma, satın alma ile biyolojik ve kimyasal silahlar ile ilgili araştırma ve geliştirme faaliyetlerinde bulunma, g) Insan hayatına zarar verecek şekilde tehlikeli madde kullanmak veya yangın, sel veya patlamaya yol açma,

h) Su, enerji ve diğer doğal kaynaklarına insan hayatın tehlikeye atacak şsekilde müdahale etme,

ı) Yukarıdaki eylemlerden birini gerçekleştirme tehdidinde bulunma".

Şunu da belirtmek gerekir ki, 15 Mart 2017 tarihli 2017/541 sayılı Terörizmle Mücadeleye ilişkin Avrupa Konseyi Kararı da terör suçları kavramını 2002/475/JHA sayılı Konsey Kararı ile neredeyse aynı şekilde tanımlamaktadır. ${ }^{82}$

ABAD, Lounani Kararında B ve D Kararında olduğu gibi Birleşmiş Milletler'in amaç ve ilkelerine aykırı bir fiil kavramını BM Güvenlik Konseyi’nin terörizmle mücadele ile ilgili kararları ışığında yorumlamıştır. ${ }^{83} \mathrm{Bu}$ yorum metodunu izleyerek Mahkeme "terör eylemleri, yöntemleri ve uygulamaları Birleşmiş Milletler'in amaç ve ilkelerine aykırl aykırıdır" ve "kasten terör eylemlerini finanse etmek, planlamak ve azmettirmek de Birleşmiş Milletler' in amaç ve ilkelerine aykurıdır" demiştir. ${ }^{84} \mathrm{I} \mathrm{lk}$ sorunun cevabına ilişkin olarak Mahkeme Vasıf Yönergesi m. 12(2)(c)'de yer alan hariçte bırakma hükmünün sadece 2002/475 sayılı Çerçeve Kararı m.1 (1)'de yer alan bir veya birden fazla terör suçundan hüküm giymiş olmayı kapsamadığını, Vasıf Yönergesinin ilgili hükmünün kapsamının daha geniş olduğunu belirtmiştir. ${ }^{85}$

Mahkemeye yönlendirilen ikinci soru şu şekildedir:

“Bay Lounani’nin Belçika Ceza Mahkemesi tarafindan terör örgütüne üyelik suçundan 16 Şubat 2006'da suçlu bulunması 2004/83 sayılı Vasıf Yönergesi m. 12(2)(c)'de geçen Birleşmiş Milletler'in amaç ve ilkelerine aykırı bir fiil olarak kabul edilebilir mi?" iken üçüncü soru ise şöyledir:

"Mülteci statüsünden hariç bırakılma bakımından bir siğınmacının terör örgütüne üyeliğini ve bu örgütün önde gelenlerinden olduğunu tespit eden bir ceza mahkemesi kararı kişi şahsen terör eylemlerinde bulunmasa, buna teşebbüs etmese ve terör eyleminde bulunma tehdidinde bulunmasa dahi kişinin Birleşmiş Milletler'in amaç ve ilkelerine aykırı suç işlediği, azmettirdiği veya iştirak ettiği anlamın taşır mı? veyahut böyle bir durumda her vakıanın ayrl ayr incelenmesi ve 2002/475 sayll Avrupa Konseyi Çerçeve Kararı m. 1'de tanımlanan terör suçlarına katılma ve azmettirmenin var olup olmadığının belirlenmesi mi gerekir?" ${ }^{86}$

$\mathrm{ABAD}$, kendisine yöneltilen soruların aslında terör örgütü eylemlerine katılm kişi şahsen terör eyleminde veya terör eylemi tehdidinde bulunmasa bile uluslararası

\footnotetext{
82 Bkz. Directive (EU) 2017/541 of the European Parliament and of the Council of 15 March 2017 on combating terrorism and replacing Council Framework Decision 2002/475/JHA and amending Council Decision 2005/671/JHA, OJ L 88, 31.3.2017, p. 6-21.

83 ABAD, Lounani Kararı, para 45.

84 ibid, para 45.

85 ibid, para 48-54.

86 ibid, para 39.
} 
korumadan hariç tutulma nedeni sayılır mı sorusu olduğunu belirtmiş̧tir. Mahkeme ilk olarak terörizmle mücadele ile ilgili BM Güvenlik Konseyi Kararlarına atıfta bulunarak "Birleşmiş Milletler'in amaç ve ilkelerine aykırı filler terör eylemleri ile sınırlı değildir." demiştir. ${ }^{87}$ Burada Mahkeme ilk olarak yabancı savaşanların yani vatandaşı oldukları veya ikamet ettikleri ülkelerden diğer ülkelere terör eylemlerini planlamak veya bu eylemlere katılmak amacıyla giden kişilerin giderek daha da önemli bir sorun haline geldiğini kaydeden 2178 (2014) sayılı BM Güvenlik Konseyi Kararı'na ${ }^{88}$ atıfta bulunmuştur. 2178 sayılı BM Güvenlik Konseyi Kararı şu düzenlemeyi içermektedir:

"Üye Devletler... terörist eylemlerin sürdürülmesi, planlanmast ya da hazılanması ya da kattlimı amactyla, ikamet ettikleri Devlet ya da uyrukluktan başka bir Devlete seyahat eden yabancı savaş̧̧ların örgüte alınmasın (recruitment), örgütlenmesini, taşınmasını ya da donatılmasını veya bu savaş̧̧ılara terör eğitiminin sağlanmasın veya seyahatlerinin ve faaliyetlerinin finanse edilmesini engelleyecektir."

BM Güvenlik Konseyi Kararını yoruma esas alarak ABAD, mülteci statüsünden hariç bırakma hükmünün sadece terör eylemlerini gerçekleştiren kişileri değil aynı zamanda terör eylemleri için hazırlık yapan, terör eylemlerini planlama ve gerçekleştirme amacıyla yabancı savaş̧̧ıları örgüte alan, bu kişilerin örgütlenmesini, taşınmasını ya da donatılmasını sağlayan, bu kişilere terör eğitimi veren, seyahatlerini ve terör faaliyetlerini finanse eden kişileri de kapsadığını belirtmiştir. ${ }^{89}$ Daha önce de belirtildiği üzere $\mathrm{ABAD}$ mülteci statüsünden hariçte bırakma için kişinin işlediği suçun 13 Haziran 2002 tarihli ve 2002/475/JHA sayılı Konsey Çerçeve Kararı'nda sayılan terör suçlarından biri olmasına gerek olmadığını kaydetmiş̧ir. ABAD, Mustafa Lounani’nin 2002 y1lından günümüze BM terör örgütü listesinde yer alan uluslararası bir terör örgütünün yönetim kademesinde yer aldığını ve bu örgütün uluslararası faaliyetleri kapsamında Irak'a gitmek isteyen yabancı savaşanlar için sahte pasaport hazırlanmasına ve bu kişilerin Irak'a gidişlerinin kolaylaştırılmasına yardım ederek lojistik destek sağladığını belirtip, bu eylemlerin mülteci statüsünden hariçte bırakma kapsamına girebileceğini tespit etmiş̧ir. ${ }^{90}$ Ayrıca, ABAD, kişinin bir ceza mahkemesi kararı ile terör örgütüne üyelik suçunu işlediğinin ve bu örgütün önde gelen üyeleri veya liderleri arasında yer aldığının tespitinin kişinin mülteci statüsünden hariç tutulmasına ilişkin değerlendirmede dikkate alınması gereken önemli bir unsur olduğunu belirtmiştir. ${ }^{91}$

Lounani Kararının değerlendirilmesine geçmek gerekir ise, ABAD bu karar ile Mustafa Lounani gibi terör örgütünün önde gelen üyelerinden olan ve bu rolü

\footnotetext{
87 ibid, para $66,67$.

88 BM Güvenlik Konseyi’nin 24 Eylül 2014 günü 7272. oturumunda kabul edilen (2014) 2178 sayılı Kararı, <http://www. un.org/en/ga/search/view_doc.asp?symbol=S/RES/2178\%20\%282014\%29 > erişim tarihi: 5 Şubat 2019 (S/RES/2178 (2014)).

89 ibid, para 69.

90 ibid, para 73,74 .

91 ibid, para 78.
} 
kapsamında yabancı savaşanların seyahati için sahte pasaport hazırlayan bir kişinin doğrudan terör eylemlerine katılmasa dahi Birleşmiş Milletler'in amaç ve ilkelerine aykırı hareket ettiğini kabul etmiştir. ${ }^{92}$ Mahkeme Lounani Kararında B ve D Kararına nazaran Birleşmiş Milletler'in amaç ve ilkelerine aykırı fiil kavramını daha geniş yorumlamıştır. Lounani Kararı birçok yönden Mahkeme'nin 2010 tarihli B ve D Kararına benzerlik göstermektedir: ilk olarak, her iki kararda da Birleşmiş Milletler'in amaç ve ilkelerine aykırı fiil kavramları BM Güvenlik Konseyi Kararları ışı̆̆ıında yorumlanmıştır. ${ }^{93} \mathrm{Bu}$ da demek oluyor ki; Divan şimdi olduğu gibi gelecekte de BM Güvenlik Konseyinin terörle mücadele konusunda aldığı kararları ve bu kararlardaki terörizm ve terörizmle mücadele kapsamına giren eylemleri mülteci statüsünden hariç bırakmaya ilişkin kararlarında dikkate alacaktır. İkinci olarak, her iki kararda da ABAD kişinin terör örgütüne üyeliği ve terör suçlarını işlediği bir mahkeme kararı ile sabit olsa dahi bunun kişiyi doğrudan mülteci statüsünden hariç bırakmadığını, hariçte bırakmaya ilişkin değerlendirmenin her kişi ve vakıa için ayrı ayrı ve kişinin içinde bulunduğu durum, örgütteki rolü, terör eylemlerine ne derece katıldığı ve örgüt eylemlerindeki sorumluluğu gibi özel durumların dikkate alınarak yapılmas1 gerektiğini belirtmiştir. ${ }^{94}$ Bununla birlikte B ve D Kararından farklı olarak ABAD Lounani Kararında, kişinin terör örgütüne üyeliği ve terör suçlarını işlediğine dair bir mahkeme kararının hariçte tutulmaya ilişkin değerlendirmede dikkate alınması gereken önemli bir unsur olduğunu belirtmiştir. ${ }^{95}$

\section{Avrupa Birliği Adalet Divanı'nın Terör Örgütü ile İlişkisi Olan Kişilerin Mülteci Statüsünden Hariç Bırakılması İle İlgili İçtihadının Değerlendirilmesi}

$\mathrm{Bu}$ çalışmada incelenen ABAD kararlarını akademik çalışmalar 1şığında değerlendirdiğimizde $\mathrm{AB}$ hukukunda terör ile ilişkisi olan kişilerin mülteci statüsünden hariç bırakılmasına ilişkin dört ana ilkeye ulaşmak mümkündür.

İlk olarak, ABAD'ın B ve D Kararında ve Lounani Kararında belirttiği üzere, terörizm 1951 Sözleşmesi m. 1 F ve Vasıf Yönergesi m. 12 uyarınca hem Birleşmiş Milletler'in amaç ve ilkelerine aykırı bir fiil hem de ağır bir siyasi olmayan suç kapsamına girebilmektedir. Bununla birlikte, bir terör eyleminin veya terör örgütüne üyeliğin BM ilke ve amaçlarına aykırı fil sayılabilmesi için genellikle terör eyleminin veya örgütün eylemlerinin uluslararası nitelikte olması veya uluslararası unsurlara sahip olması aranmaktadır. ${ }^{96}$

\footnotetext{
92 Stephen Coutts, 'Terror and Exclusion in EU Asylum Law Case - C-573/14 Lounani (Grand Chamber, 31 January 2017)', European Law Blog, 3 Mart 2017, <http://europeanlawblog.eu/2017/03/03/terror-and-exclusion-in-eu-asylum-law-case-c57314-lounani-grand-chamber-31-january-2017/> erişim tarihi: 5 Şubat 2019.

93 ibid.

94 ibid.

95 ibid.

96 European Asylum Support Office (EASO), 'Practical Guide: Exclusion' (2017) < https://www.easo.europa.eu/sites/default/
} 
İkinci olarak, $\mathrm{ABAD}, \mathrm{B}$ ve $\mathrm{D}, \mathrm{T}$ ve Lounani Kararlarında da görüldüğü üzere Birleşmiş Milletler'in amaç ve ilkelerine aykırı fil kavramını terörle mücadeleyi konu edinen güncel BM Güvenlik Konseyi Kararları 1şı̆̆ında yorumlamaktadır. ${ }^{97}$ ABAD'ın bu yaklaşımı bazı yazarlar tarafından mülteci statüsünden hariç bırakma hükümlerinin kapsamını öngörülemeyecek şekilde genişlettiğinden bahisle eleştirilmiştir. ${ }^{98}$ Bilindiği üzere, BM Güvenlik Konseyi beş sürekli üye başta olmak üzere toplam 15 üyenin görüşlerini yansıtan bir BM organıdır. Divanın BM Güvenlik Konseyi kararlarını yoruma esas alan bu yaklaşımı şu sonucu doğurmaktadır: BM Güvenlik Konseyi terör ile ilgili kavramları daha geniş yorumladıkça ve terörle mücadeleye yönelik devletlerin ödevlerinin kapsamını genişlettikçe, Vasıf Yönergesi uyarınca mülteci statüsünden hariç bırakmanın kapsamı da genişleyecek ve hariçte bırakılan kişilerin sayısı artacaktır. Örnek vermek gerekirse, 28 Eylül 2001 tarihli 1373 sayılı BM Güvenlik Konseyi Kararında terör eylemleri, yöntemleri ve uygulamalarını gerçekleştirmek ile terör eylemlerini bilerek finanse etmek, planlamak ve teşvik etmek Birleşmiş Milletler'in amaç ve ilkelerine aykırı olarak tespit edilmişken, 2014 tarihli 2178 sayılı BM Güvenlik Konseyi Kararında yabancı savaşç1ların örgüte alınması, örgütlenmesi, taşınması, donatılması ve bu savaşçılara terör eğitiminin sağlanması da Birleşmiş Milletler'in amaç ve ilkelerine aykırı fiil olarak kabul edilmiştir. Söz konusu BM Güvenlik Konseyi kararlarını mülteci statüsünden hariç bırakma nedenlerinin yorumunda esas alarak $\mathrm{ABAD}$, bugün sadece terör eylemlerini doğrudan gerçekleştiren kişilerin değil terör eylemlerini bilerek finanse eden, planlayan, teşvik eden, yabancı savaşanları örgüte dahil eden, yabancı savaşanların bir ülkeden diğerine seyahatine, örgütlenmesine ve bu kişilere ekipman sağlanmasına yardım eden kişilerin de mülteci statüsünden hariçte bırakılabileceğine karar vermiştir. Şunu da belirtmek gerekir ki; ABAD her ne kadar Güvenlik Konseyi Kararlarını hükme esas alsa da BM Genel Kurulu'nun terörizme ilişkin kararları ve raporlarına kararlarında atıfta bulunmamıştır.

Üçüncü olarak, ABAD, B ve D Kararında ve Lounani Kararında, bir kişinin terör örgütüne üye olmasının o kişiyi otomatik olarak mülteci statüsünden hariç bırakmayacağını tespit etmiştir. ${ }^{99} \mathrm{ABAD}$ 'n yerleşik içtihadına göre, hariç bırakma kararının verilebilmesi için mülteci statüsünden hariç bırakma nedenlerinin kişi bakımından var olup olmadığına ilişkin bireysel, detaylı ve kapsamlı bir inceleme yapılmalıdır. T Kararında da görüldüğü üzere bir mültecinin ikamet izninin iptaline ilişkin değerlendirmenin bile ABAD'a göre vakıa bazında yapılması gerekmektedir.

files/EASO $\% 20$ Practical $\% 20$ Guide $\% 20-\% 20$ Exclusion $\% 20 \% 28$ final $\% 20$ for $\% 20$ web $\% 29$.pdf $>$ erişim tarihi: 5 Şubat 2019, s. 28.

97 Bkz. Steve Peers, 'Foreign fighters' helpers excluded from refugee status: the ECJ clarifies the law', EU Law Analysis, 31 Ocak 2017 <http://eulawanalysis.blogspot.com/2017/01/foreign-fighters-helpers-excluded-from.html> erişim tarihi: 5 Şubat 2019.

98 Gilbert, s. 514; Guy S. Goodwin-Gill and Jane McAdam, The Refugee in International Law, 3rd edn, Oxford University Press, 2007, Oxford, 194, 195.

99 Kosinski, s. 444. 
B ve D ve Lounani Kararlarında da belirtildiği üzere, mülteci statüsünden hariç tutulmaya ilişkin incelemede $\mathrm{ABAD}$ olaydaki olguların, söz konusu kişinin üye olduğu, faaliyetlerine katıldığı veya desteklediği terör örgütünün eylemlerinin hariçte bırakma kapsamına girip girmediğinin ve kişinin bu fillerin işlenmesindeki sorumluluğunun dikkate alınmasını öngörmektedir.

$\mathrm{ABAD}$ içtihadına göre bir kişinin terör örgütünün eylemlerindeki sorumluluğu değerlendirilirken ise kişinin örgütteki görevi ve rütbesi, mülteci statüsünden hariçte bırakmaya neden olan eylemlerde oynadığı rol, kişinin örgüt eylemleri ile ilgili sahip olduğu veya olduğunu sandığı bilgi ve özgür iradesi ile mi örgüte üye olup bu üyelik kapsamında terör eylemlerinde rol aldığı dikkate alınacaktır. Venier ve Venturi bu tür vakıa bazında bir değerlendirmenin tehdit, hile, istismar sonucu yani iradesi dışında terör örgütüne dahil edilmiş kişilerin mülteci statüsünden hariçte bırakılmaması sonucunu doğurduğunu ve dolayısıyla $\mathrm{ABAD}$ 'ın bu içtihadının yerinde olduğunu savunmaktadır. ${ }^{100} \mathrm{ABAD}$ 'ın bu içtihadının $\mathrm{AB}$ üyesi devletlerin ulusal mahkemelerince de benimsendiğini söyleyebiliriz: örneğin, İngiliz Yüksek Mahkemesi, JS Kararında vakıa bazında bireysel değerlendirmenin önemine dikkat çekmiş ve hariçte bırakmaya ilişkin bir karar verilebilmesi için mültecinin örgüt eylemleri kapsamında terör eylemlerinin işlenmesine hatırı sayılır derecede katkıda bulunmuş olmasını aramıştır. ${ }^{101}$

Dördüncü olarak, bir kişinin örgüt üyeliğinin veya terör suçu işlediğinin bir ulusal ceza mahkemesinin kararı ile sabit olması ve kişinin üyesi olduğu örgütün $\mathrm{BM}$ ve $\mathrm{AB}$ terör örgütü listelerinde yer alması kişinin mülteci statüsünden hariç bırakılmasına ilişkin değerlendirmede kişinin mülteci statüsünden hariçte bırakılması yönünde dikkate alınacak hususlardandır. Bu ilkeyi ABAD'ın B ve D ve Lounani kararlarından çıkartmak mümkündür. ${ }^{102}$

\section{Sonuç}

Avrupa Polis Teşkilatı (Europol) 2017 yılı içerisinde Avrupa Birliği içerisinde 205 terör saldırısının engellediğini, gerçekleşen terör saldırılarında ise 768 kişinin hayatını kaybettiğini, 844 kişinin ise yaralandığını kaydetmiştir. ${ }^{103}$ Europol aynı zamanda 2017 yılında yine Birlik içinde 1219 kişinin terör ile ilişkili suçlardan tutuklandığını kaydetmiştir. ${ }^{104} \mathrm{Bu}$ veriler terörizmin uluslararası toplumda olduğu gibi Avrupa Birliği için de çok önemli bir tehdit oluşturduğunu göstermektedir. Avrupa Birliği'nde olduğu gibi terörizm ülkemizde de ulusal güvenlik ve kamu düzenine karşı süregelen önemli bir tehdittir.

\footnotetext{
100 Venier ve Venturi, s. 17.

101 JS (Sri Lanka) v Secretary of State for the Home Department [2010] UKSC 15, para 31.

102 Peers, 'Foreign fighsters' helpers excluded from refugee status: the ECJ clarifies the law'.

103 Europol, 'European Union Terrorism Situation and Trend Report 2018', (2018) <https://www.europol.europa.eu/activitiesservices/main-reports/european-union-terrorism-situation-and-trend-report-2018-tesat-2018> erişim tarihi: 5 Şubat 2019, s. 9

104 ibid, s.10.
} 
Makalede belirtildiği üzere, uluslararası hukukta mülteci statüsünden hariç bırakma, 1951 Sözleşmesi m. 1 F ile düzenlenmiştir. 1951 Sözleşmesinde yer alan mülteci statüsünden hariçte bırakma nedenleri sınırlı olarak sayılmıştır ve maddenin lafzı, sözleşmesinin konusu, bütünü ve amacı dikkate alındığında bu hükmün ve mülteci statüsünden hariçte bırakma nedenlerinin dar şekilde yorumlanması gerekmektedir. ${ }^{105}$ Günümüzde terör ile ilişkisi olan kişilerin mülteci statüsünden hariç tutulması devletlerin terörizmle mücadele ve ulusal güvenliği koruma amaçlı meşru politikaları ile Mültecilerin Hukuki Statüsüne dair Sözleşmede yer alan ve dar yorumlanması gereken uluslararası korumadan hariç bırakma hükümlerinin karşı karşıya geldiği bir konudur. Yabancılar ve Uluslararası Koruma Kanunumuzdaki birçok düzenlemenin kaynağının Avrupa Birliği Hukuku olması ve hem YUKK hem de Vasıf Yönergesinde mülteci statüsünden hariç bırakma hususunun 1951 Sözleşmesi m. $1 \mathrm{~F}$ esas alınarak düzenlenmesi, ABAD içtihadının Türk mahkemeleri için de yol gösterici nitelikte olabileceğini göstermektedir.

Bu çalışmada Avrupa Birliği Adalet Divanı'nın terörizm ve mülteci statüsünden hariç bırakma ve ikamet izin iptaline ilişkin verdiği C-57/09 ve C-101/09 sayılı B ve D Kararı, C-373/13 sayılı T Kararı ve C-573/15 sayılı Lounani Kararı incelenmiş ve bu inceleme sonucunda terör ile ilişkisi olan kişilerin mülteci statüsünden hariçte bırakılmasına ilişkin dört ana ilke tespit edilmiştir. İlk olarak, terör hem 1951 Sözleşmesi m. 1 F (b)'de yer alan ağır bir siyasi olmayan suç hem de m. 1 F (c)'de yer alan Birleşmiş Milletler'in amaç ve ilkelerine aykırı bir fiil sayılabilmektedir. $\mathrm{Bu}$ nedenle, terör örgütüne üyelik, terör faaliyetlerinde bulunmak ve terör örgütüne destek vermek bugün 1951 Sözleşmesi m. 1 F ve Vasıf Yönergesi m.12(2) kapsamına girmektedir. İkinci olarak, Birleşmiş Milletler'in amaç ve ilkelerine aykırı fiil kavramı terörle mücadeleyi konu edinen güncel BM Güvenlik Konseyi Kararları 1şığında yorumlanmalıdır. Üçüncü olarak, bir kişinin terör örgütü üyesi olduğunun, terör faaliyetleri gerçekleştirdiğinin veya terör örgütüne destek verdiğinin tespiti o kişiyi doğrudan mülteci statüsünden hariçte bırakmamalıdır. Hariç bırakmaya ilişkin değerlendirme bireysel olarak yapılmalı, bu değerlendirmede kişinin üye olduğu örgütün eylemlerinin ve kişinin örgütün hariçte bırakma kapsamına giren eylemlerinde ne şekilde yer aldığının ve bu eylemlerdeki sorumluluğunun araştırılması gerekmektedir. Son olarak, kişinin terör örgütü üyeliğine dair bir ceza mahkemesi kararı var ise veya üye olduğu örgüt $B M$ ve $A B$ terör örgütü listeleri ve kararlarında yer alıyor ise bu hususlar da mülteci statüsünden hariç bırakmaya ilişkin değerlendirmede dikkate alınmalıdır.

\footnotetext{
105 UNHCR, Background Note on the Application of the Exclusion Clauses: Article 1F of the 1951 Convention relating to the Status of Refugees, 2003, <http://www.refworld.org/docid/3f5857d24.html>, erişim tarihi: 5 Şubat 2019, para 4, 5, 7; United Kingdom Supreme Court, Al-Sirri v Secretary of State for the Home Department, [2012] UKSC 54, para 68.
} 


\section{Kaynakça/References}

Bayram, Mehmet Hanifi, Avrupa Birliği Hukuku Dersleri, 3. Bask1, Seçkin, 2018, İstanbul.

Bruin, Rene and Wouters, Kees, 'Terrorism and the Non-derogability of Non-refoulement' International Journal of Refugee Law, Volume 15(1), (2003), 5-29.

Coutts, Stephen, 'Terror and Exclusion in EU Asylum Law Case - C-573/14 Lounani (Grand Chamber, 31 January 2017)', European Law Blog, 3 Mart 2017, <http://europeanlawblog. eu/2017/03/03/terror-and-exclusion-in-eu-asylum-law-case-c-57314-lounani-grand-chamber31-january-2017/> erişim tarihi: 5 Şubat 2019.

Çiçekli, Bülent, 6458 Sayılı Kanunla Güncellenmiş Yabancılar ve Mülteciler Hukuku, 6. Bask1, Seçkin, 2015, Ankara.

Ekşi, Nuray, Mahkeme Kararları Işı̆̆ııda Suçluların İltica Sistemi Dışında Bırakılması, Beta, 2017, İstanbul.

European Asylum Support Office (EASO), 'Exclusion: Articles 12 and 17 Qualification Directive (2011/95/EU) A Judicial Analysis’, (2016) < https://www.easo.europa.eu/sites/default/files/ public/Exclusion\%20Final\%20Print\%20Version.pdf> erişim tarihi: 5 Şubat 2019.

European Asylum Support Office (EASO), 'Practical Guide: Exclusion' (2017) < https://www. easo.europa.eu/sites/default/files/EASO $\% 20$ Practical\%20Guide\%20-\%20Exclusion $\% 20$ \%28final\%20for\%20web\%29.pdf> erişim tarihi: 5 Şubat 2019.

Gilbert, Geoff 'Exclusion under Article 1F since 2001: Two Steps Backwards, One Step Forward' in V. Chetail and C. Bauloz (eds.) Research Handbook on International Law and Migration. Research Handbooks in International Law, Edward Elgar Publishing, Surrey, 2014, s. 519540 .

Goodwin-Gill, Guy S. and Jane, McAdam, The Refugee in International Law, 3rd edn, Oxford University Press, 2007, Oxford.

Güneş, Ahmet M., Avrupa Birliği Hukukuna Giriş, 2. Bask1, Onikilevha, 2016, İstanbul.

Kosinska, Anna Magdalena, 'The Problem of Exclusion from Refugee Status on the Grounds of Being Guilty of Terrorist Acts in the CJEU Case-law' European Journal of Migration and Law, Volume 19(4), (2017), s. 425-446.

Kuşçu, Döndü, Yabancılar ve Uluslararası Koruma Kanunu Hükümleri Uyarınca Yabancıların Sinır Dışı Edilmeleri, Onikilevha, 2017, İstanbul.

Lampert, Thomas, 'Prioritizing National Security at the Expense of Refugee Rights: The Effects of HT v. Land Baden-Wurttenberg' Boston College International \& Comparative Law Review, Volume 40, 2017, s. 14-27.

Monette Zard, 'Exclusion, 'Terrorism and the Refugee Convention' Forced Migration Review, Volume 32(13), (2002), s. 32-34.

Özkan, Işıl, Göç, İtica ve Sığınma Hukuku, 2. Baskı, Seçkin, 2017, Ankara.

Peers, Steve, 'Foreign fighters' helpers excluded from refugee status: the ECJ clarifies the law', EU Law Analysis, 31 Ocak $2017<$ http://eulawanalysis.blogspot.com/2017/01/foreign-fightershelpers-excluded-from.html> erişim tarihi: 5 Şubat 2019.

Peers, Steve, 'What if a refugee allegedly supports terrorism? The CJEU judgment in T' EU Law Analysis, 24 Haziran 2015, < http://eulawanalysis.blogspot.com/2015/06/what-if-refugeeallegedly-supports.html> erişim tarihi: 5 Şubat 2019.

Simeon, James C., 'Complicity and Culpability and the Exclusion of Terrorists from Convention Refugee Status Post-9/11’ Refugee Survey Quarterly, Volume 29(4), (2010) s. 104-137 
Singer, Sarah, 'The War on Terror \& Refugee Law' in S. Juss (edn) Research Handbook on International Refugee Law, Edward Elgar Publishing, forthcoming.

Singer, Sarah, Terrorism and Exclusion from Refugee Status in the UK: Asylum Seekers Suspected of Serious Criminality, Brill/Nijhoff, 2015, Leiden.

UNHCR, Background Note on the Application of the Exclusion Clauses: Article 1F of the 1951 Convention relating to the Status of Refugees, 2003, <http://www.refworld.org/docid/3f5857d24. html>, erişim tarihi: 5 Şubat 2019.

Venier Silvia, Venturi Denise, 'Linking Counter Terrorism and Refugee Law: Unravelling the (Undue) Nexus with International Law' ESIL Conference Paper Series, Volume 10, No 8, (2018), s. 1-22.

Yiğit, Özgenur, Uluslararası Hukuk, Avrupa Hukuku ve Türk Hukukunda Mülteci ve Sığınmacıların Etkili Başvuru Hakkı, Onikilevha, 2018, İstanbul.

\begin{abstract}
ABAD Kararları
C-373/13, H. T. v Land Baden-Württemberg [2015] ECLI:EU:C:2015:413.

C-57/09 and C-101/09, Bundesrepublik Deutschland $v$ B and D [2010] ECR I-10979.

C-573/15, Commissaire général aux réfugiés et aux apatrides v. Mostafa Lounani [2017] ECLI:EU:C:2017:71.
\end{abstract}

\title{
İngiliz Mahkeme Kararları
}

JS (Sri Lanka) v Secretary of State for the Home Department [2010] UKSC 15.

N2 v. Secretary of State for the Home Department (Rev 1) [2016] UKSIAC SC_125_2015.

United Kingdom Supreme Court, Al-Sirri v Secretary of State for the Home Department, [2012] UKSC 54. 